\title{
Wear and Corrosion Study of Plasma Nitriding F53 Super duplex Stainless Steel
}

\author{
Joaquim Olímpio Pereira Neto ${ }^{a}$, Raphael Oliveira da Silva ${ }^{a}$, Edilaine Honório da Silva ${ }^{b}$, Jeferson Apa- \\ recido Moreto ${ }^{c, d}$, Rafael Marinho Bandeira ${ }^{e}$, Marcos Dorigão Manfrinato ${ }^{a}$, Luciana Sgarbi Rossino ${ }^{a, f *}$ \\ ${ }^{a}$ Sorocaba Technological College - FATEC, Av. Engenheiro Carlos Reinaldo Mendes, 2015, Alto da Boa \\ Vista, Zip code 18013-280, Sorocaba, SP, Brazil \\ ${ }^{b}$ Belgian Nuclear Research Centre - SCK-CEN, Boeretang 200, 2400, Mol, Belgium \\ ${ }^{c}$ Federal Institute Goiano - IF Goiano, Rodovia Sul Goiana Km 01, Zona Rural, Zip code 75.901-970, \\ Rio Verde, GO, Brazil \\ ${ }^{d}$ Institute of Exact Sciences, Naturals and Education, Federal University of Triângulo Mineiro (UFTM), \\ Avenida Doutor Randolfo Borges Júnior, Univerdecidade, Zip code 38.064-200, Uberaba, MG, Brazil. \\ ${ }^{e}$ Department of Physical Chemistry, São Carlos Institute of Chemistry, São Paulo University, Avenida \\ Trabalhador São-carlense, 400, Zip code 13566-590, São Carlos, SP, Brazil \\ ${ }^{f}$ Federal University of São Carlos - UFSCar, Rodovia João Leme dos Santos, Km 110, Bairro do Itinga, \\ Zip code 18.052-780, Sorocaba, SP, Brazil
}

Received: October 29, 2015; Revised: July 06, 2016; Accepted: August 20, 2016

Super duplex stainless steels (SDSS) have high corrosion resistance because of their high contents of chromium, nickel, molybdenum and nitrogen but low wear resistance. To improve the wear resistance of these steels without affecting their corrosion resistance, samples of SDSS were treated by plasma ion nitriding at temperatures ranging from $350{ }^{\circ} \mathrm{C}$ to $570^{\circ} \mathrm{C}$ for two hours. This thermochemical treatment resulted in the formation of different types of nitrides that affected the microhardness, the microwear behaviour and the corrosion resistance of the metal surface. The microwear resistance decreased at $400{ }^{\circ} \mathrm{C}$ because different nitrides formed on the surface, thereby increasing the hardness and volume wear resistance of the steel. The test results showed that the alloys that were nitrided at $400{ }^{\circ} \mathrm{C}$ and $450^{\circ} \mathrm{C}$ exhibited the highest corrosion resistance to a solution medium containing chloride ions.

Keywords: Microwear, tribological, Corrosion, Expanded austenite.

\section{Introduction}

The demand for wear- and corrosion-resistant components has stimulated growing interest in surface engineering as a means of enhancing the tribological and tribochemical properties of surfaces ${ }^{1}$.

Surface and thermochemical treatments are used to improve the wear resistance of metals. Plasma ionic nitriding, which was initially developed for ferrous alloys, is widely used for this purpose. In this treatment, nitrogen atoms are dissociated, ionised and transported at high velocities up to the surface of the metal part. A characteristic layer is created via the diffusion of nitrogen on the metal surface, and the properties of this surface layer can be modified by varying the process parameters ${ }^{2}$.

Plasma ion nitriding produces hard and wear-resistant surfaces via the formation of precipitates on the metal surface. Manfrinato ${ }^{3}$ has reported that this technique does not affect the metallic structure of the material and is efficient and not harmful to the environment because gases that are usually present in the atmosphere are used in the process.

*e-mail: lu.sgarbi@yahoo.com
The plasma ion nitriding process is generally used to improve the surface hardness and wear resistance of a material. This process improves the corrosion resistance of a metal, as has been verified for SDSS ASTM A182. However, Liang ${ }^{4}$ has reported that relatively high temperatures increase the surface hardness and reduce the corrosion resistance of a metal because of the formation of chromium nitride $(\mathrm{CrN})$. $\mathrm{CrN}$ is a phase that is fairly stable, brittle and less resistant to corrosion than the substrate ${ }^{4}$.

Super duplex stainless steel ASTMA182 has an austenitic/ ferritic structure with phases that are formed in exact proportion due to their chemical composition and thermal treatment. In addition to a high $\% \mathrm{Cr}$ content, these alloys are characterised by a low carbon content " $<0.03 \%$ in weight" and contain alloy elements such as molybdenum, tungsten, copper and nitrogen ${ }^{5}$. These steels are called special alloys and are used in locations with aggressive atmospheres that require high corrosion resistance, in oil platforms, for offshore activities, such as oil exploration, in piping systems, in evaporators, in distillers, and in storage tanks, among others ${ }^{6}$.

The objective of this study was to investigate the wear and corrosion resistance of SDSS ASTM A182 with and without surface treatment. The surface treatment that was used in the study was plasma ion nitriding at different temperatures. 


\section{Materials \& Methods}

The material used in this work was SDSS ASTM 18210 (which is also known as F-53). Table 1 shows the actual (wt $\%$ ) and nominal chemical compositions. Chemical analyses were performed in an optical emission spectrometer (Amtek, model Spectromax).

The specimens that were used in this study had dimensions of $30 \times 20 \times 10 \mathrm{~mm}$. The plasma ion nitriding process was conducted at the Physics Department of the Federal University of São Carlos (Universidade Federal de São Carlos - UFSCar). The following initial parameters were used: a total pressure of $300 \mathrm{~Pa}$, a gas mixture of $80 \% \mathrm{H}_{2}$ and $20 \% \mathrm{~N}_{2}$, constant voltage of $350-400 \mathrm{~V}$ and duration of two hours. The treatment temperatures were $350{ }^{\circ} \mathrm{C}, 400{ }^{\circ} \mathrm{C}$, $450^{\circ} \mathrm{C}, 500^{\circ} \mathrm{C}, 550^{\circ} \mathrm{C}$ and $570^{\circ} \mathrm{C}$, in the order presented. The profiles of the nitrided layer at different temperatures were characterised using an Oxford Instruments scanning electron microscope (SEM), model Incax-Sight. X-ray dispersive energy spectroscopy (XDES) was used to verify the percentage of nitrogen in the nitrided layer.

The X-ray diffraction analyses were performed at the University of São Paulo (Universidade de São Paulo) - Lorena Campus using a LabXShimadizu, model XRD-600 instrument. The time of analysis was 30 minutes for each nitrided sample at the different aforementioned temperatures, with a source voltage and an amperage of $40 \mathrm{kV}$ and $30 \mathrm{~mA}$, respectively, using a grazing incidence angle and a molybdenum filter.

Two kind of test system can be used to analyses the microwear of the material behavior. They can be carried out with either the fixed ball type of system or the free ball test system ${ }^{7}$. The fixed ball configuration is used to promote high normal contact load and consequently high stress in the contact. On the other hand, the free ball configuration result in low normal load in the test. By enabling a wide adjust range, the fixed ball test system is broadly used to study the microwear in a variety of materials.

The microwear tests were carried out using a fixed ball microwear device, as can be seen in Figure $1^{8}$. In this technique, a ball often of bearing steel, is pressed against the test sample in the presence or not of an abrasive slurry. The ball is clamped between coaxial shafts and driven by an electric motor. A flat specimen was mounted horizontally on the ball and is loaded against the ball by a dead weight. This microwear test produces a circular depression in the sample that can be measured (Figure 2) to determine the wear rate of the coating, and under some conditions the substrate material. After wear testing the wear scars was observed by optical microscopy (OM) to identify the dominant wear mechanism.
In this work a 52100 steel ball with $25.4 \mathrm{~mm}$ of diameter was used under a controlled contact load. The fixed frequency used in this test was $744 \mathrm{rpm}$. The normal loads used in the wear tests of the base material were 16 and $8.3 \mathrm{~N}$, and the tests time were 2, $5,10,15,20,30$ and 40 minutes. For the samples that received a surface treatment, the normal load used was $16 \mathrm{~N}$ and the test time 10 minutes. The tests were performed without any type of abrasive or lubricant liquid. After the tests were completed, the samples were analysed by OM using an OLYMPUS stereoscope, model SZ61, with a 6 Megapixel camera and Software analysis 2.0 , which was used to measure the diameters and the crater radio generated in a coated system by rotation of the ball.

The wear volume (V) was defined by equation (2.1), where $(\mathrm{C})$ represents the sliding distance and $(\mathrm{K})$ the wear rate, determined by equation (2.2) and (2.3) respectively. The depth of the crater penetration was determined using equation $(2.4)^{9}$ :

$$
\begin{aligned}
& V=\frac{\pi b^{4}}{64 r} \quad b<<<<r \\
& C=(2 \pi r) .(R P M) .(t) \\
& K=\frac{V}{N C} \\
& H=\sqrt{\frac{V}{\pi r}}
\end{aligned}
$$

where "b" denotes the diameter of the wear crater, " $r$ " the radius of the standard ball that was used in the test, " $\mathrm{t}$ " is the test time, and $\mathrm{N}$ represents the normal load applied in the wear test.

Open circuit potential tests were performed to characterise the thermodynamic tendency of the F-53 steel to corrosion. The corrosion potential $\left(\mathrm{E}_{\text {corr }}\right)$ was monitored for 4000 seconds before the potentiodynamic polarisation tests was performed.

The potentiodynamic polarisation tests were performed according to standard ASTM-G61 using an AUTOLAB potentiostat/galvanostat that was coupled to a personal computer for data control and processing. A singlecompartment electrochemical cell with three electrodes was used in the test. The following electrodes were used: a work electrode (WE) of F-53 steel with a one-squarecentimetre exposed area against a platinum electrode (CE) and a reference electrode (RE) of silver-silver chloride $\left(\mathrm{Ag} / \mathrm{AgCl}_{\text {sat }}\right)$. The electrochemical experiments were performed at $25^{\circ} \mathrm{C}$ using a $0.6 \mathrm{M} \mathrm{NaCl}$ solution. 
Table 1: Chemical composition (wt $\%$ ) and nominal chemical composition of F-53 steel

\begin{tabular}{lccccccccccc}
\hline Element & $\% \mathrm{C}$ & $\% \mathrm{Si}$ & $\% \mathrm{Mn}$ & $\% \mathrm{P}$ & $\% \mathrm{~S}$ & $\% \mathrm{Cr}$ & $\% \mathrm{Mo}$ & $\% \mathrm{Ni}$ & $\mathrm{N}$ & $\mathrm{Fe}$ \\
\hline Exp. & .029 & .46 & .99 & .0032 & .0005 & 24.6 & 3.6 & 7.3 & 0.245 & 62.6 \\
Nom. & .03 & .8 & 1.2 & 0.5 & 0.02 & $24-26$ & $3-5$ & $6-8$ & $.24-.32$ & - \\
\hline
\end{tabular}

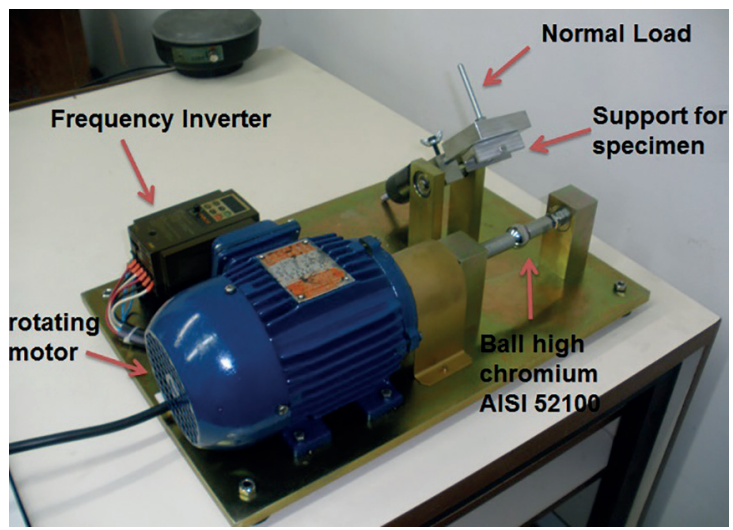

Figure 1: Microwear device.

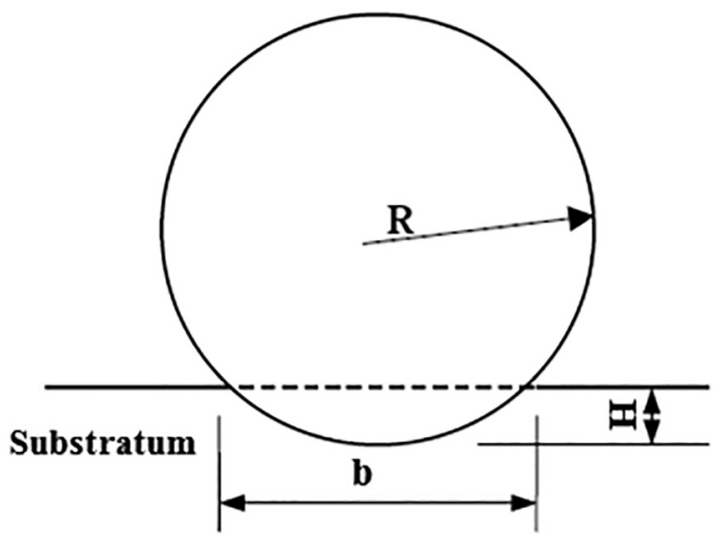

Figure 2: Circular depression geometry (wear scar) produced in microwear test.

\section{Results \& Discussion}

\subsection{Base Material Metallography}

Figure 3 shows the biphasic microstructure of the base material, which consisted of a matrix of austenite "CFC" $(\gamma)$ and ferrite "CCC" $(\alpha)$. The black spots were most likely inclusions that were created in the steel production process.

\subsection{Wear tests on the base material}

Figure 4 shows the caps that were produced in the microwear test for different sliding distances (under a 16-N load). The cap diameter was observed to increase with the sliding distance. However, the increase in the diameter was not linearly proportional to the sliding distance, that is, doubling the wear time did not double the diameter of the printed cap, even though continuous progressive wear was observed as the diameter increased.

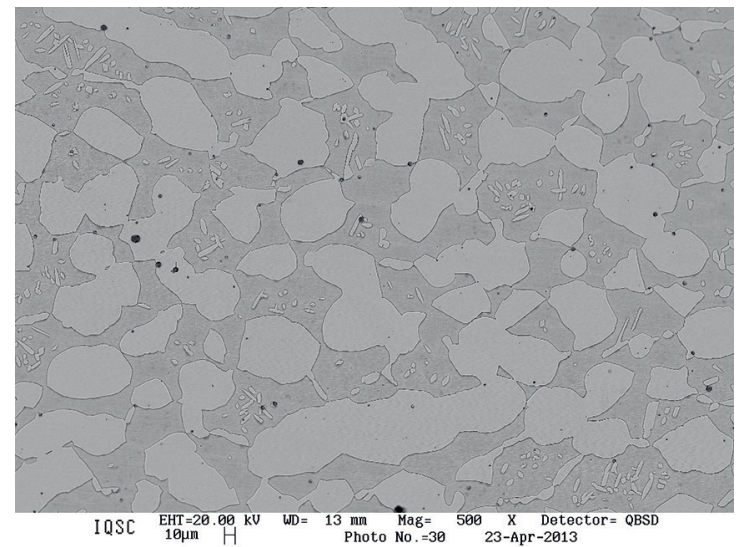

Figure 3: SEM micrograph of F-53 steel; Beraha reagent was used for chemical attack.

The volume of wear has a linear relation with the product of the sliding distance, normal force and wear coefficient ${ }^{9,10}$. The wear coefficient is constant with the time when the constant regime of wear is reached. In other hands, the analysis of the volume of wear in function of slide distance can be used to determine when the constant regime is reached. In fact, the constant regime was reached if it presents a linear variation with the sliding distance ${ }^{11}$.

The combination of the application of high loads under insufficient lubrication can cause severe adhesive wear on the surface of sliding metallic components. This damage is characterised by the presence of macroscopically visible fragments that adhere onto the two contact surfaces ${ }^{12}$. In our case, metal particles adhered to the respective sphere, which increased the severity of the wear on the material and left a wear track on the sphere. Abrasive wear between two bodies was the predominant wear mechanism that was observed in the tests that were performed in the present study, which resulted in macroscopic parallel lines that are called grooves ${ }^{13}$.

Figure 5 shows the caps resulting from the analysis of the test that was performed under an 8.3-N load, demonstrating that the samples suffered abrasive wear between two bodies.

The caps that formed in the test under a $16-\mathrm{N}$ load had larger diameters than those that were obtained in the tests under an 8.3-N load for the same test time, i.e., the decrease in the cap diameter could be attributed to the diminution of the applied load. A visual inspection of Figure 5 shows that the wear volume progressively increased with the sliding distance and was similar but less intense than the behaviour of the wear volume under the 16-N load. 


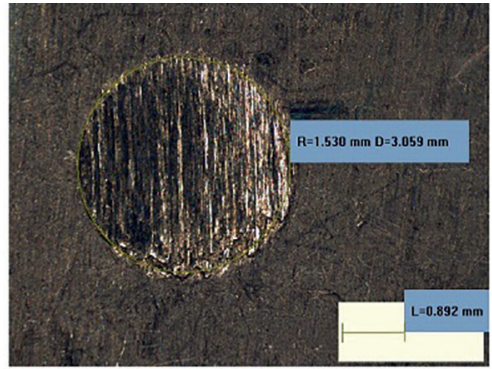

(a)

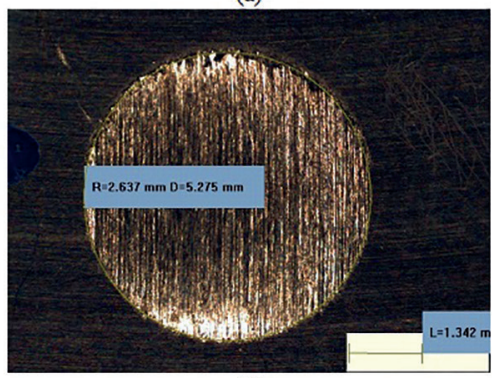

(d)

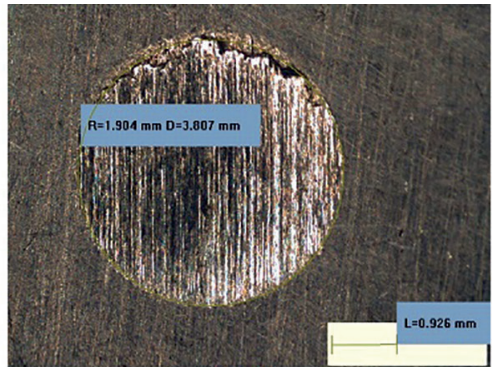

(b)

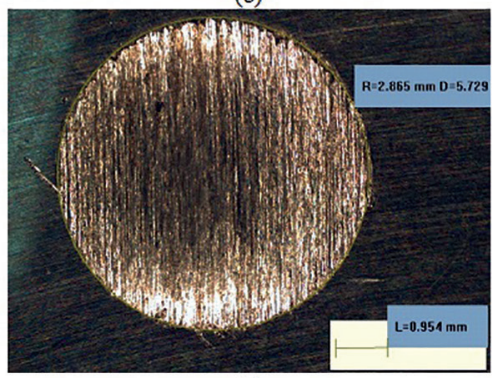

(e)

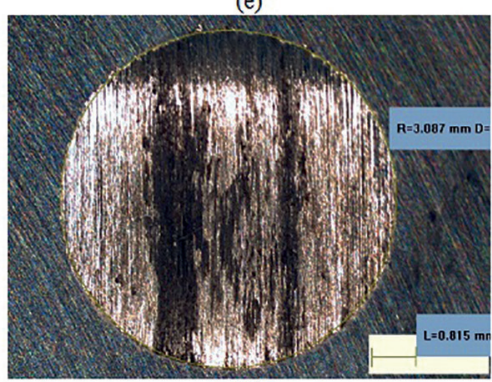

(g)

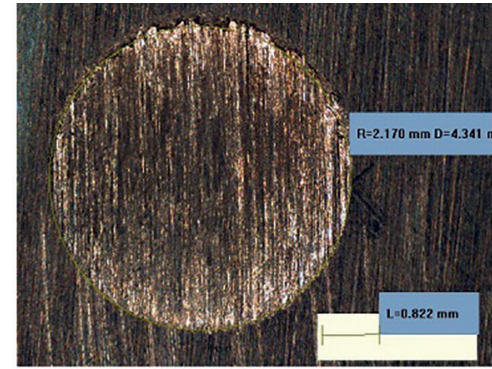

(c)

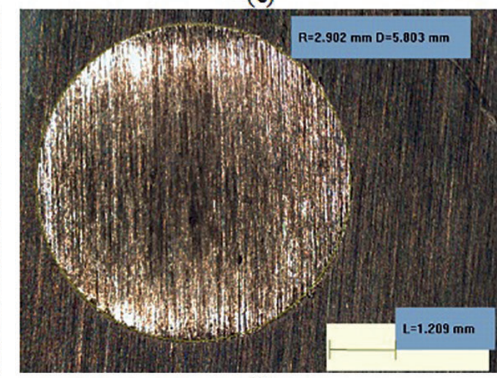

(f)

Figure 4: Caps produced in the microwear test for different sliding distances under a 16-N load at (A) 2 minutes, (B) 5 minutes, (C) 10 minutes, (D) 15 minutes, (E) 20 minutes, (F) 30 minutes and (G) 40 minutes.

The formation of an oxide layer was observed in the print of the cap in Figure $5(\mathrm{~F})$. The presence of this oxide inhibited damage from wear and protected the surface during abrasion. However, increasing the test time (or the sliding distance) resulted in the removal of the oxide (Figure $5(\mathrm{G})$ ).

The presence of the oxide layer was much more evident in the test under the 8.3-N load than under the 16-N load because film formation was facilitated at low loads. A protective film was formed in the 16-N test; however, this test was twice as severe as the $8.3-\mathrm{N}$ test, and the film was removed before it could attain the structure that was observed in the 8.3-N test.

The formation of the oxide layer can be explained in terms of the effects of factors such as the temperature and the ease of passivation of the steel. Faria ${ }^{14}$ reported that the oxidation film that is involved in the contact between two sliding metallic surfaces forms at high temperatures or ambient temperature and occurs at the contact between points of roughness.

Figure 6 (A) shows that the test that was performed under a $16-\mathrm{N}$ load was more severe and had a lower rate of variation in the wear than the test that was performed under an 8.3-N load. This latter result was obtained because the less severe test under an 8.3-N load did not prevent the protective oxide layer from forming on the material surface. This phenomenon was only observed at low loads.

We consider that the formation and detachment of the oxide caused the large variation in the wear rate for different sliding distances under the 8.3-N normal load. The low observed wear rates for long sliding distances facilitated oxide formation because of the temperature of the tested surface. Increasing the severity of the test, i.e., increasing extrinsic parameters, such as the applied load, resulted in the rapid removal of the oxide layer that formed on the surface of the material. However, a more detailed study must be conducted to confirm this effect.

Figure 6 (B) shows that the wear volume increased with the normal load, i.e., the severity of the wear depended on the load. The wear volume increased with the sliding distance for both the normal loads of $16 \mathrm{~N}$ and $8.3 \mathrm{~N}$. The wear volume diminished and stabilised after $1250 \mathrm{~m}$, even when the sliding distance was increased further. Cozza ${ }^{12}$ considered that this phenomenon may indicate a permanent wear regime. 


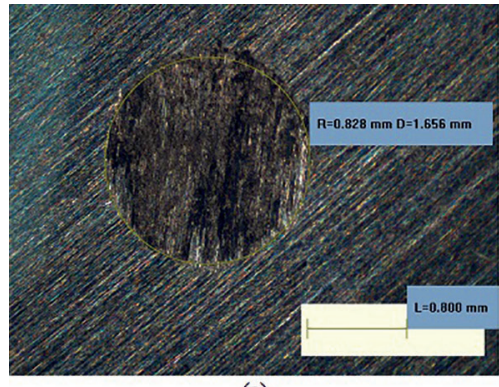

(a)

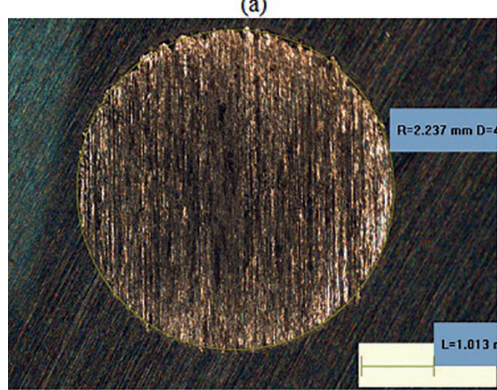

(d)

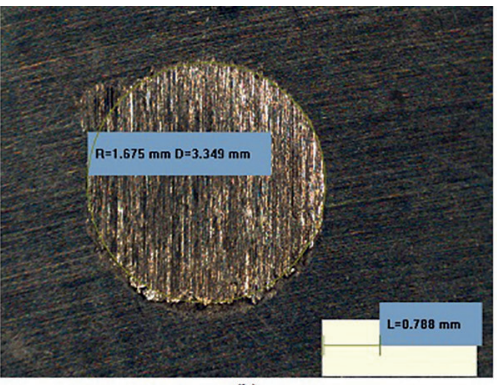

(b)

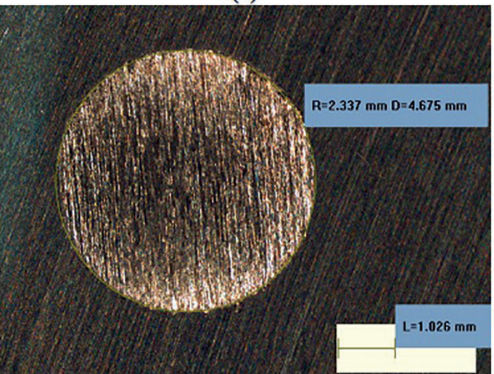

(e)

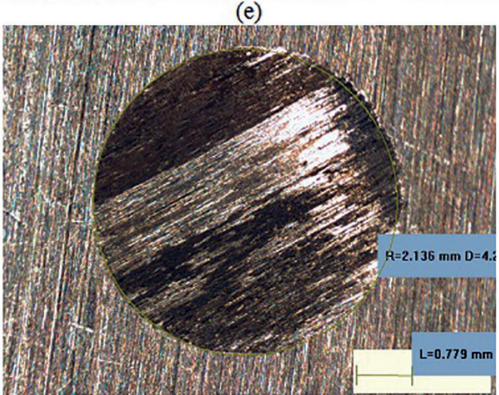

(g)

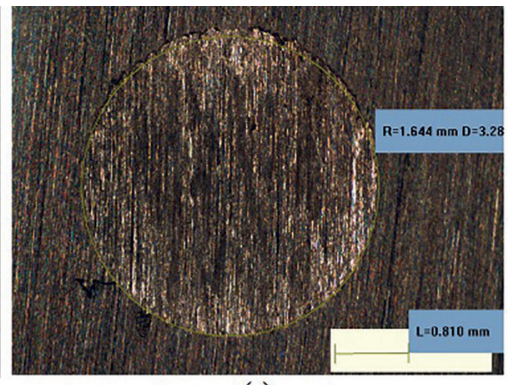

(c)

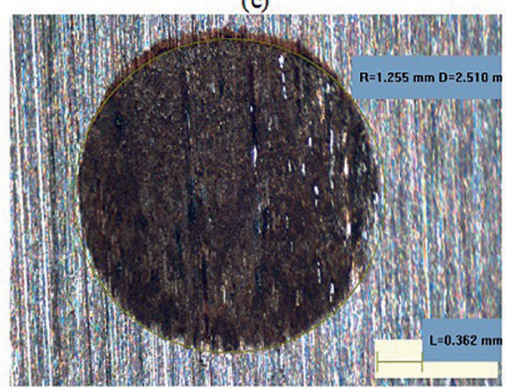

(f)

Figure 5: Caps produced in the microwear test for different sliding distances under an 8.3-N load at (A) 2 minutes, (B) 5 minutes, (C) 10 minutes, (D) 15 minutes, (E) 20 minutes, (F) 30 minutes and (G) 40 minutes.

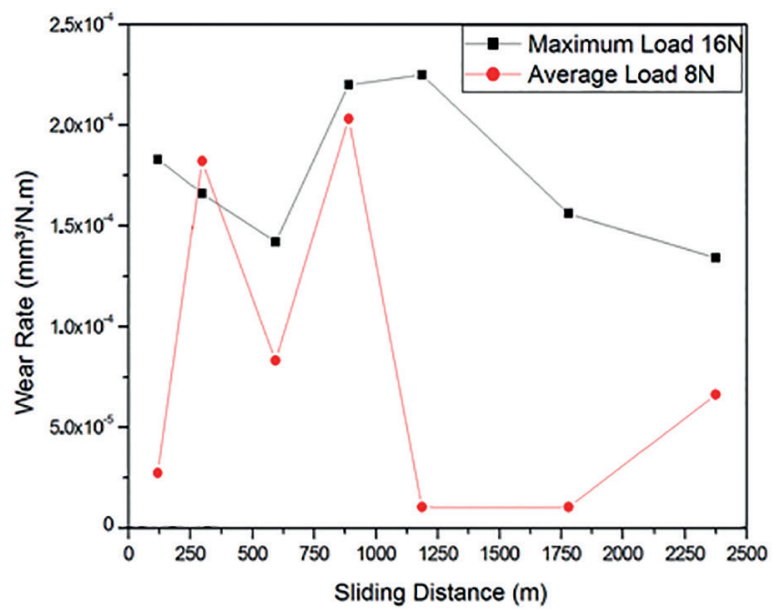

(a)

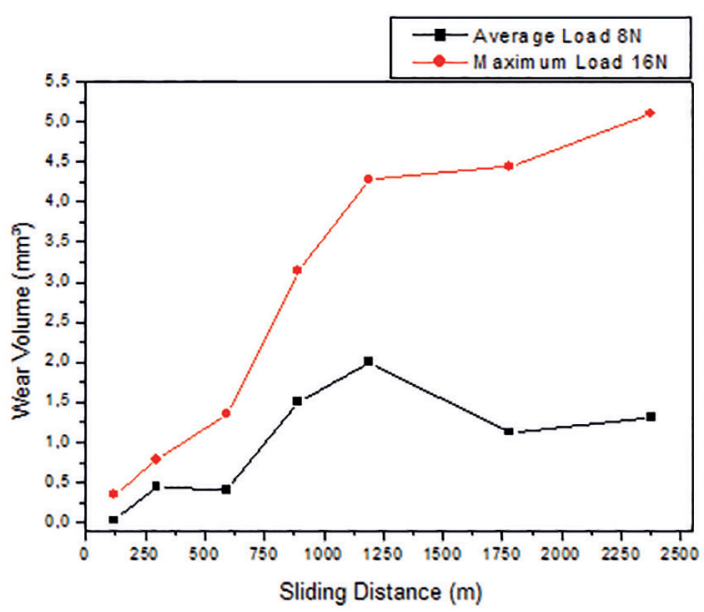

(b)

Figure 6: (A) Change in the wear rate with the sliding distance and (B) wear volume as a function of the covered distance for 16-N and 8-N loads. 
The diminution of the wear volume and the consequent increase in the material wear resistance of the material under an 8.3-N load for sliding distances above $1250 \mathrm{~m}$ may be related to the formation of an oxide layer under the test conditions, as previously discussed.

Quinn ${ }^{15,16}$ reported on studies in which a reduction of wear in steels was observed because of the formation of $\mathrm{Fe}_{2} \mathrm{O}_{3}$ oxide, which protects the surface against damage. The presence of oxides in the wear products has been observed in both dry and lubricated sliding.

The effect of oxidative wear in the test under the 8.3-N load in this study could be confirmed by constructing curves of the wear rate under the contact load to illustrate the wear transition that has been described by Cozza [12]. Further tests under different loads should be performed in a future study for this purpose.

\subsection{Microhardness of the nitrided surface}

Figure 7 (A) shows the microhardness as a function of the thickness of the nitrogen layer that was formed on the material under study by the nitriding treatment. The microhardness increased with the thickness. Points 2, 3, 4, 5, 6 and 7 show the microhardness values for the nitrided materials, and point 1 shows that of the untreated material.

The material surface hardness increased significantly with the thickness of the nitrogen layer; the hardness of point "7" (for nitriding at $570{ }^{\circ} \mathrm{C}$ ) was almost 3.7 times higher than that of point " 2 " (for nitriding at $350{ }^{\circ} \mathrm{C}$ ). Thus, the nitrogen saturation on the material surface increased with the nitriding temperature, which promoted the formation of the hardening phases. Therefore, the diffusion of nitrogen increased with the surface hardness of the material.

Figure $7(\mathrm{~B})$ is a plot of the plasma ion nitriding process temperature as a function of the microhardness, which supports the previous explanation that the microhardness increased with the thickness of the nitrogen layer. The hardness did not increase in linear proportion to the temperature because the thickness of the diffusion nitrogen layer was not linearly proportional to the treatment temperature. However, increasing any one of the three parameters of the hardness, the temperature and the nitrogen layer caused the other two parameters to increase.

\subsection{Wear tests on the nitrided material}

Figure 8 shows the results of the abrasive wear tests on the nitrided material. Figure 8 (A) shows that a very intense scratching process occurred along with the grooving phenomenon. The wear resistance of the material that was nitrided at $350{ }^{\circ} \mathrm{C}$ remained low compared to that obtained at the other treatment temperatures because of the thinness of the nitrogen layer that was produced at $350^{\circ} \mathrm{C}$. However, Figure 8 (B) shows that the wear resistance of the material that was nitrided at $400{ }^{\circ} \mathrm{C}$ increased because of the diffusion nitrogen layer.

Figure 8 (C) clearly shows that the lowest wear rate was obtained by nitriding at $450{ }^{\circ} \mathrm{C}$. The printed cap was very small with a $0.57-\mathrm{mm}$ diameter. This phenomenon occurred because the increased temperature of the plasma ion nitriding process affected the formation of the hardening phases. But, with the temperature high to $500^{\circ} \mathrm{C}, 550^{\circ} \mathrm{C}$ and $570{ }^{\circ} \mathrm{C}$ (Figure $8 \mathrm{~d}, 8 \mathrm{e}$ and $8 \mathrm{f}$, respectively), the printed cap high determining the high of the volume of wear.

Figure 9(A) shows that the material had the lowest wear rate for the $450^{\circ} \mathrm{C}$ treatment. The wear rate reached a maximum for the $500{ }^{\circ} \mathrm{C}$ treatment and then began to decrease. Figure 9(B) was used to analyse the wear resistance of the material. The wear resistance increased such that the highest tribological resistance was observed for the 400 ${ }^{\circ} \mathrm{C}$ treatment. There was a $99.9998 \%$ increase in the wear resistance at this treatment temperature.

When the temperature of the thermochemical treatment was increased above $500{ }^{\circ} \mathrm{C}$, the surface hardness increased (Figure 7(B)) but the wear resistance was diminished. This behaviour occurred because the layer attained a very high

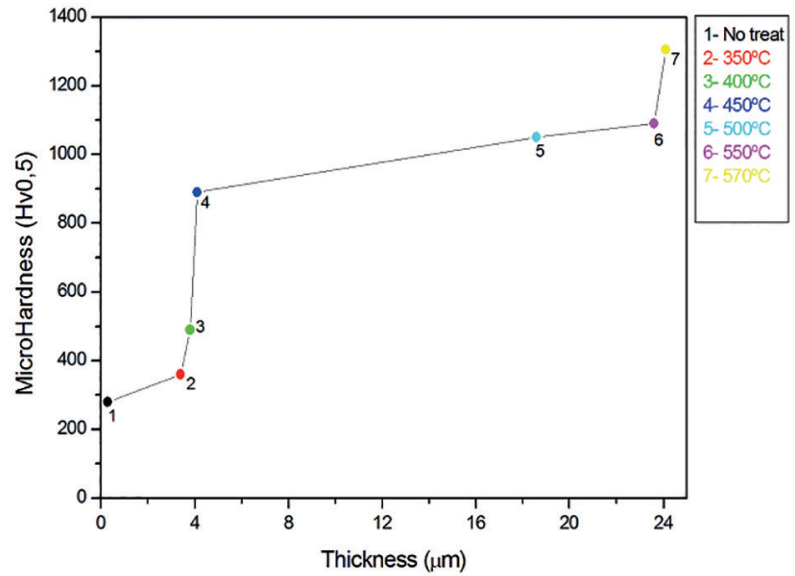

(a)

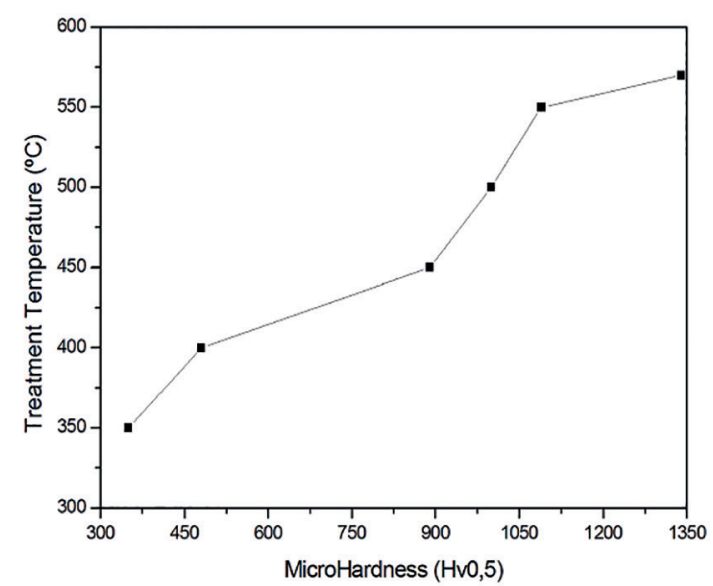

(b)

Figure 7: Microhardness as a function of (A) the layer thickness and (B) the treatment temperature. 


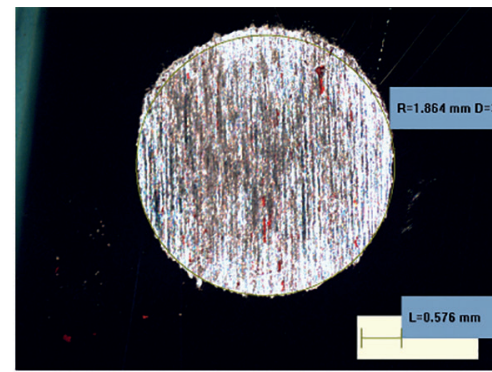

(a)

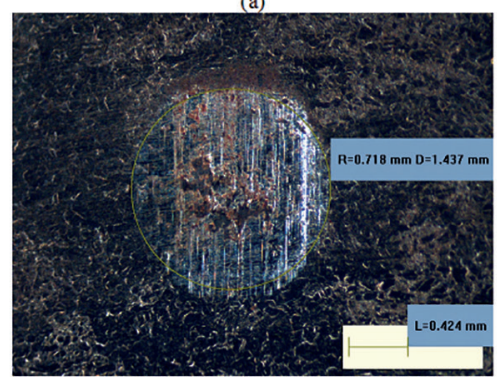

(d)

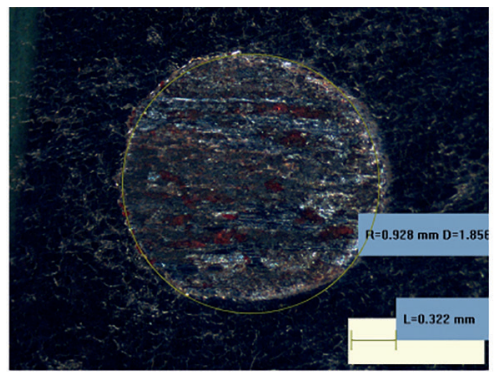

(b)

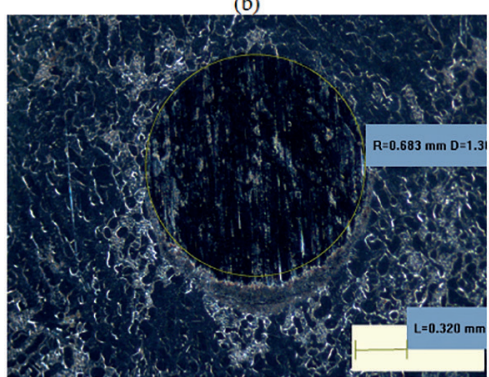

(e)

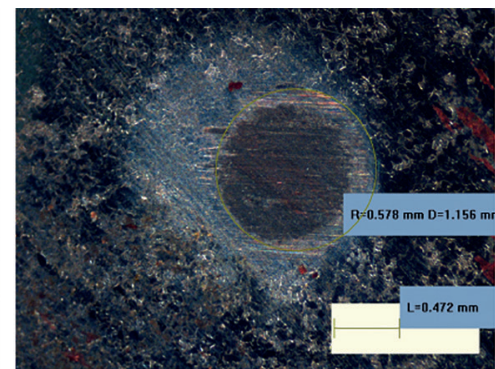

(c)

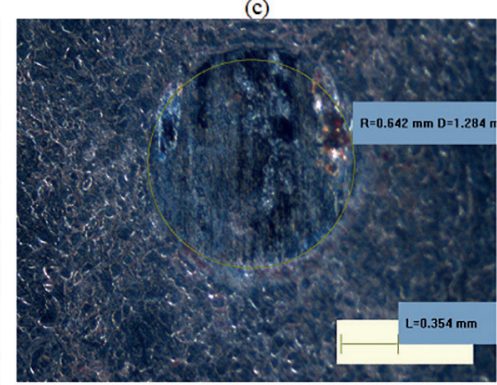

(f)

Figure 8: Caps produced in wear tests of nitrided materials under a maximum load of $16 \mathrm{~N}$ at (A) $350{ }^{\circ} \mathrm{C}$, (B) $400{ }^{\circ} \mathrm{C},(\mathrm{C}) 450{ }^{\circ} \mathrm{C}$, (D) $500{ }^{\circ} \mathrm{C}$, (E) $550{ }^{\circ} \mathrm{C}$ and (F) $570^{\circ} \mathrm{C}$.

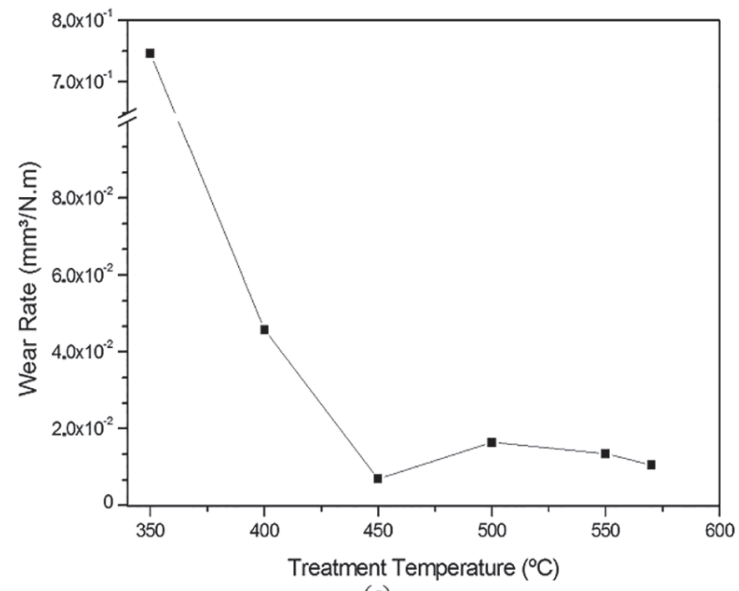

(a)

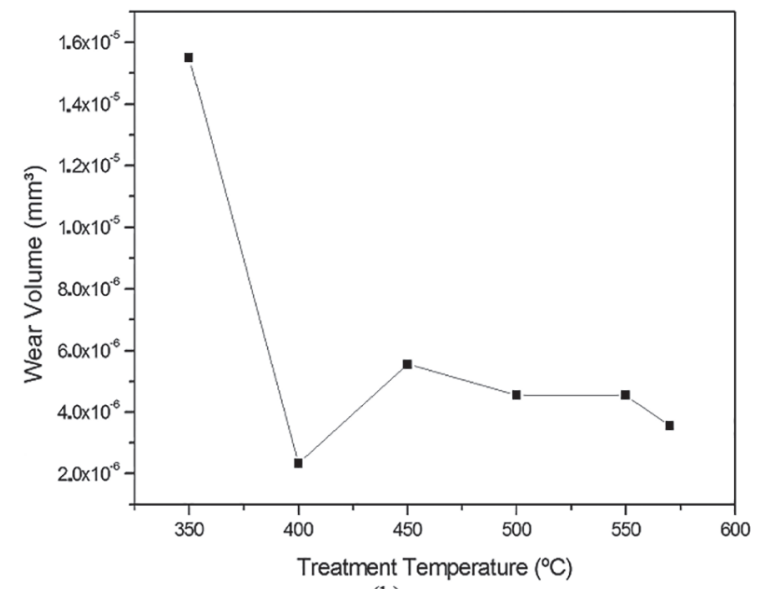

(b)

Figure 9: (A) Wear rate and (B) wear resistance of the material as a function of the nitriding temperature.

microhardness of $1300 \mathrm{HV}$, and as reported by Dalibon ${ }^{17}$, this extremely hard surface behaves in a brittle manner when it suffers abrasive wear under compression, where the breakage negatively affects the wear resistance.

In addition to the reduction in the wear resistance, some researchers have observed a decrease in the corrosion resistance of stainless steel as the nitriding temperature is increased. This result is obtained because of $\mathrm{Cr}$ impoverishing in a solid solution and the formation of hardening phases of nitrides ${ }^{6}$.

\subsection{Composition of the nitrided layer}

Figure 10 shows the metallography of the layers that were formed by the ion nitriding treatment. The clearer part represents the substrate. The layer originated in the bakelite/ substrate interface. Table 2 shows the quantity of nitrogen (by $w t \%)$ at the interface points. At each treatment temperature, points $\mathrm{A}$ and $\mathrm{B}$ had higher nitrogen concentrations than point $\mathrm{C}$, showing the efficiency of the plasma nitriding process.

Layer formation occurred by nitrogen diffusion on the material surface, which explained the increase in the layer thickness after the diffusion coefficient increased exponentially with temperature ${ }^{18}$. Figure 11 clearly shows that the thickness of the nitrogen diffusion layer increased with the treatment temperature.

However, the reverse diffusion phenomenon may occur when the temperature of plasma ion nitriding process is 


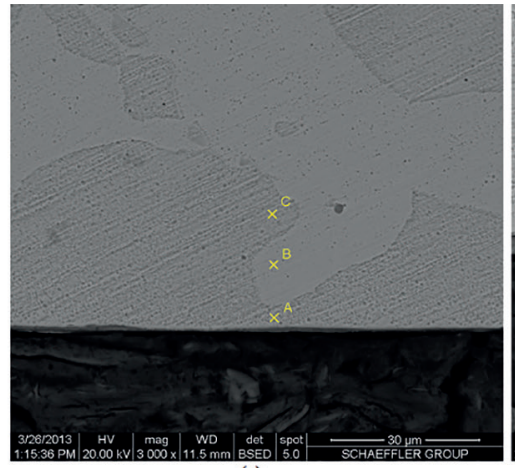

(a)

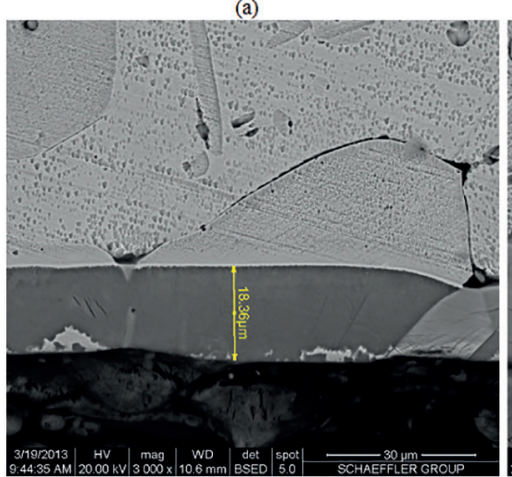

(d)

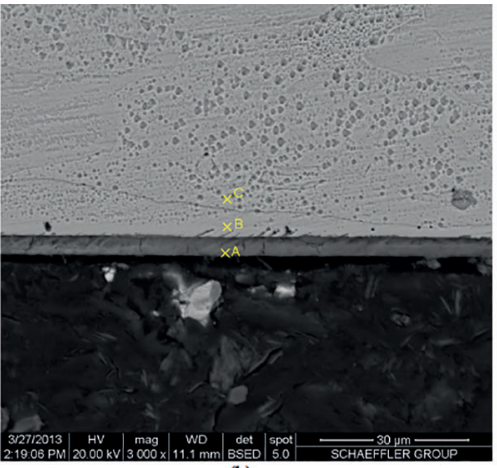

(b)

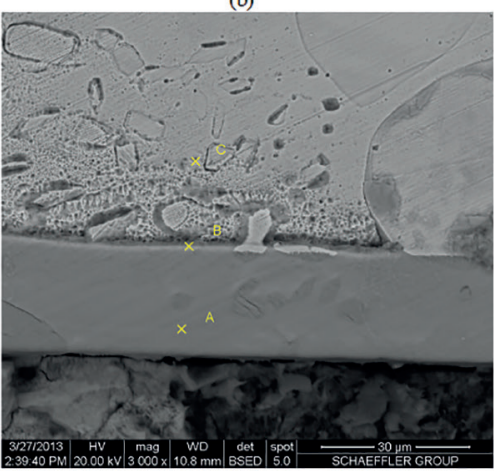

(e)

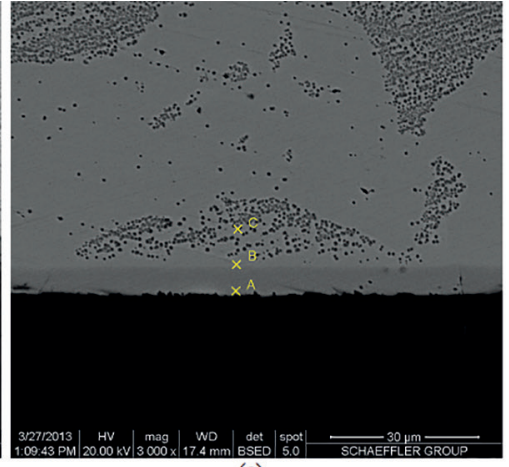

(c)

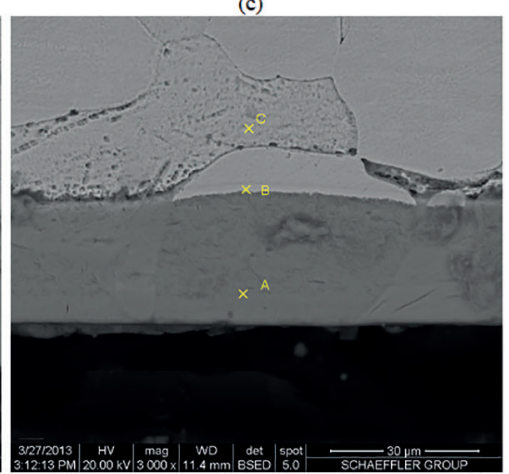

(f)

Figure 10: Micrography of the nitrided layers at different nitriding temperatures: (A) $350{ }^{\circ} \mathrm{C}$, (B) $400{ }^{\circ} \mathrm{C},(\mathrm{C}) 450{ }^{\circ} \mathrm{C}$, (D) $500{ }^{\circ} \mathrm{C}$, (E) $550{ }^{\circ} \mathrm{C}$ and (F) $570{ }^{\circ} \mathrm{C}$.

Table 2: Chemical composition along the layer at points A, B and C

\begin{tabular}{cccccccc}
\hline Element & Points & $350^{\circ} \mathrm{C}$ & $400^{\circ} \mathrm{C}$ & $450^{\circ} \mathrm{C}$ & $500{ }^{\circ} \mathrm{C}$ & $550^{\circ} \mathrm{C}$ & $570^{\circ} \mathrm{C}$ \\
\hline \multirow{3}{*}{ Nitrogen } & $\mathrm{A}$ & $1.34 \%$ & $2.06 \%$ & $7.83 \%$ & $10.37 \%$ & $7.83 \%$ & $11.96 \%$ \\
& $\mathrm{~B}$ & $1.03 \%$ & $2.54 \%$ & $5.27 \%$ & $1.65 \%$ & $6.09 \%$ & $5.60 \%$ \\
& $\mathrm{C}$ & $0.39 \%$ & $0.91 \%$ & $2.15 \%$ & $1.11 \%$ & $1.70 \%$ & $1.82 \%$ \\
\hline
\end{tabular}

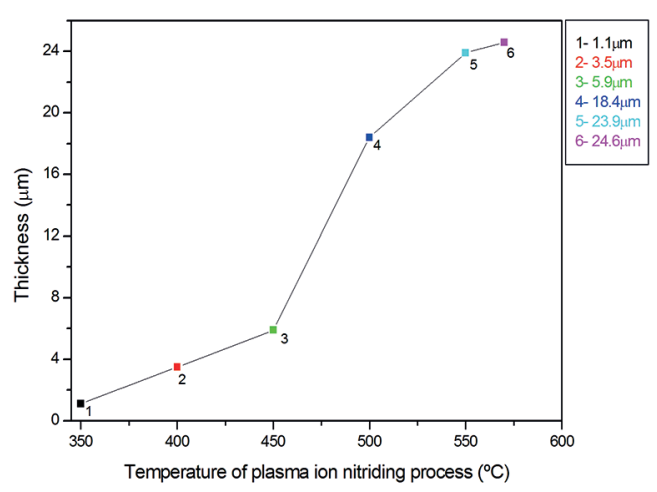

Figure 11: Thickness of the nitrided layer as a function of the treatment temperature. increased. The thickness of the nitrided layer increased with the temperature, but this phenomenon was not always observed. Reis ${ }^{19}$ has shown that increasing the nitriding temperature of a $316 \mathrm{~L}$ steel to $750^{\circ} \mathrm{C}, 850^{\circ} \mathrm{C}$ and $1150^{\circ} \mathrm{C}$ decreased the thickness of the diffused layer to $264.2 \mu \mathrm{m}$, $181.6 \mu \mathrm{m}$ and $12.8 \mu \mathrm{m}$, respectively.

\subsection{X-ray diffraction analysis}

Figure 12 shows the different substances that formed on the surface of the F-53 steel. In SDSS, the formation of hardening layers, which are called nitrides, during the plasma nitriding process can improve the mechanical properties of the material surface. For example, chromium nitrides increase the surface hardness but drastically reduce corrosion resistance, which, according to the literature, is not desirable in many situations. 


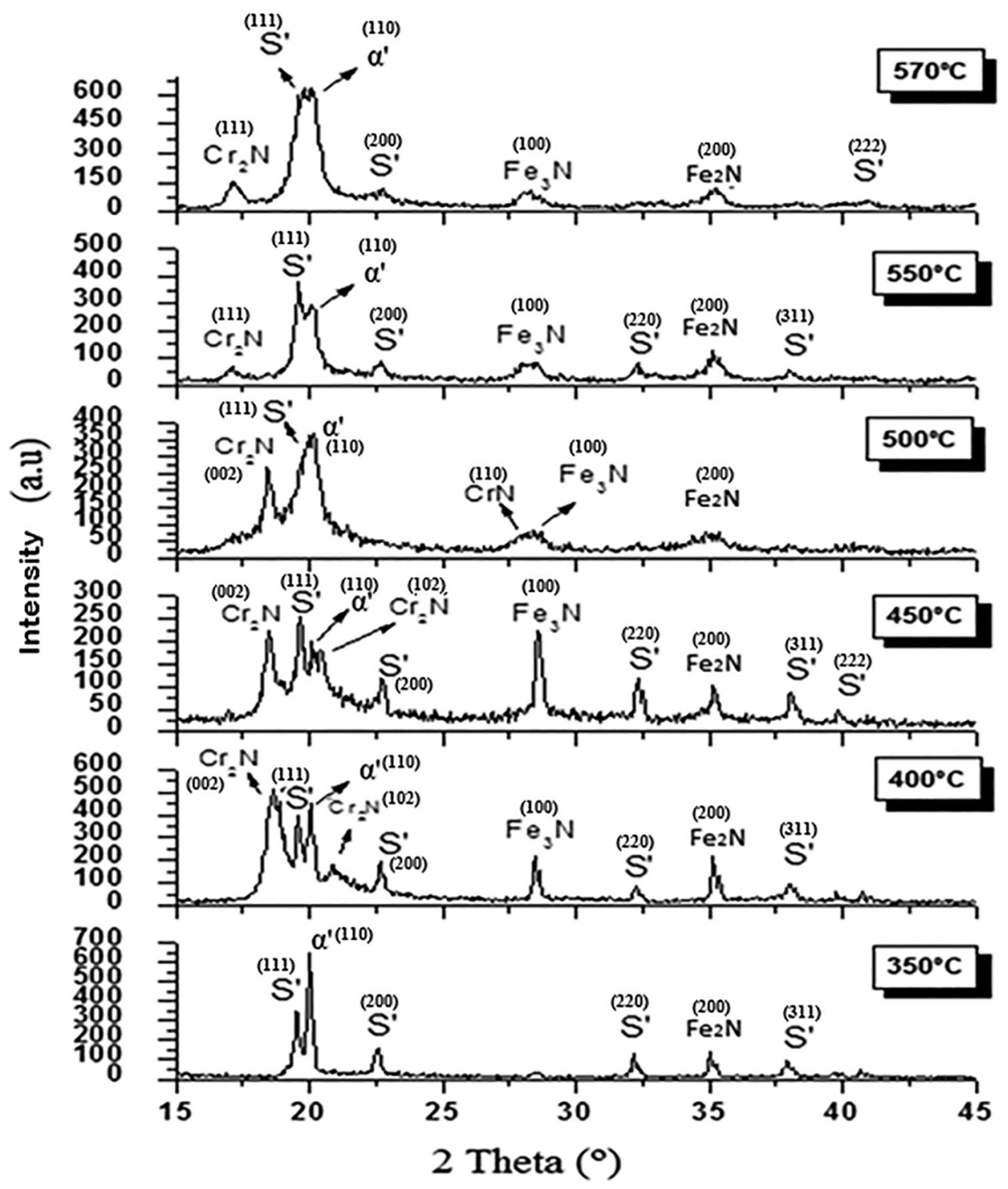

Figure 12: X-ray diffractograms for various nitriding conditions.

However, the formation of the S' phase or expanded austenite results in high mechanical resistance and compressive strength with high hardness because of the insertion of nitrogen as an interstitial solid solution in the crystal lattice. The resulting distortions in the lattice impede defect motion, thus providing good wear resistance. The $\alpha$ ' phase, or expanded ferrite, exhibits the same characteristics as the S' phase but has less capability to solubilise nitrogen in the interstices because of the lower lattice parameter of the $\alpha^{\prime}$ phase $^{20}$.

The formation the S' phase was preferred, and only $\mathrm{Fe}_{2} \mathrm{~N}$ nitrides were formed at the treatment temperature of the plasma ion nitriding process $\left(350^{\circ} \mathrm{C}\right)$. However, the thin diffusion layer that formed was able to increase the wear resistance of the material by five thousand times over that of the base material.
In addition to the formation of the S' phase, the formation of hardening phases, such as $\mathrm{Cr}_{2} \mathrm{~N}, \mathrm{Fe}_{3} \mathrm{~N}$ and $\mathrm{Fe}_{2} \mathrm{~N}$, was also initiated at $400{ }^{\circ} \mathrm{C}$. Both nitrides exhibited high hardnesses. Pinedo $^{1}$ has reported that chromium nitride is harder than iron nitride. The S' and $\alpha$ ' phases were also present, which contributed to the reduction in the wear rate.

Figure 12 shows that the diffractogram that was obtained at $450{ }^{\circ} \mathrm{C}$ was very similar to that obtained at $400{ }^{\circ} \mathrm{C}$, with very intense peaks in the 19 to $21^{\circ}$ range that corresponded to the formation of $\mathrm{Cr}_{2} \mathrm{~N}, \mathrm{~S}^{\prime}, \alpha^{\prime}$ and other substances, such as $\mathrm{Fe}_{3} \mathrm{~N}$ and $\mathrm{Fe}_{2} \mathrm{~N}$, along the DR-x angles. At this temperature, higher amount of different types of S' phases were observed, although the layer was not very thick, being only $59.32 \%$ thicker than that obtained at $400{ }^{\circ} \mathrm{C}$.

The plasma ion nitriding process was inefficient at 500 ${ }^{\circ} \mathrm{C}$. This result was obtained because of the formation of the 
S' phase and different types of nitrides, such as $\mathrm{CrN}, \mathrm{Cr}_{2} \mathrm{~N}$, $\mathrm{Fe}_{2} \mathrm{~N}$ and $\mathrm{Fe}_{3} \mathrm{~N}$, which resulted in a very high hardness and an increase in the wear rate of the material surface. Nitrides are very hard and cannot withstand compressive abrasive wear, breakage and increases in the wear rate.

The layer thickness at $570{ }^{\circ} \mathrm{C}$ was $2.85 \%$ thicker than that at $550{ }^{\circ} \mathrm{C}$, which in turn resulted in a lower wear rate than that at $500{ }^{\circ} \mathrm{C}$.

The wear resistance of the nitrided material increased because of the presence of different types of S' phases that produced the tribological properties of the formed layer. This phase was created by nitrogen supersaturation in the austenitic matrix, where the phase remained as a solid solution that occupied the octahedral voids of the face-centred cubic crystal lattice. The interstitial element was present in much higher quantities than the solubility limit, which resulted in an elastically distorted and thermodynamically metastable structure. This structure promoted a state of residual compressive stresses, which resulted in a high hardening effect from the phases that formed during the nitriding process. However, the elastic modulus of expanded austenite remained unchanged ${ }^{21}$, which enhanced the material wear resistance. Nie, Leyland and Matthews ${ }^{22}$ and Tschiptschin and Pinedo ${ }^{23}$ have reported that the stresses in the substrate/ coating interface can be minimised by matching the elastic modulus of the coating to that of the substrate, which enhances the system performance. Thus, the formation of expanded austenite should enhance the tribological properties of steel because expanded austenite has a hardening effect and its elasticity modulus is near that of the substrate ${ }^{23}$.

\subsection{Corrosion tests}

Figure 13 shows the open circuit potential curves of F-53 steel at different nitriding temperatures over a 4000 -second period before the potentiodynamic polarisation tests were performed. Note that all of the tests were repeated three times and showed good reproducibility. The results of the F-53 steel potentiodynamic polarisations at different nitriding temperatures are shown in Figure 14.

The open circuit potential curves showed that F- 53 steel had a higher corrosion resistance at $400{ }^{\circ} \mathrm{C}$ and $450{ }^{\circ} \mathrm{C}$ (see the $\mathrm{E}_{\text {corr }}$ values). The results of the open circuit potential tests showed that the steel that was nitrided at $400{ }^{\circ} \mathrm{C}$ stabilised within a few minutes.

The potentiodynamic polarisation curves of the material showed different behaviours for different nitriding temperatures. F-53 steel that was treated at $400{ }^{\circ} \mathrm{C}$ and $450{ }^{\circ} \mathrm{C}$ exhibited superior resistance to corrosion and very similar corrosion current densities $\left(\mathrm{i}_{\text {corr }}\right)$, which indicated that almost the same area was occupied by the cathodic sites at both temperatures. These results corroborated the results of the $\mathrm{X}$-ray diffraction analyses, that is, almost the same phases, $\mathrm{Cr}_{2} \mathrm{~N}, \mathrm{~S}^{\prime}$ and $\alpha^{\prime}$, formed in the material at both temperatures. Note that a much larger passive region formed at $400^{\circ} \mathrm{C}$ and $450{ }^{\circ} \mathrm{C}$ than at the other temperatures.

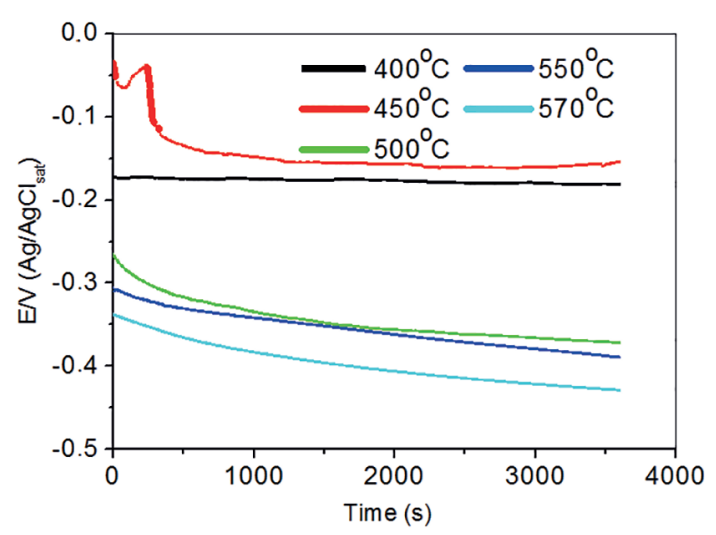

Figure 13: F-53 steel open circuit potential measurements at different nitriding temperatures for an immersion period of 4000 seconds.

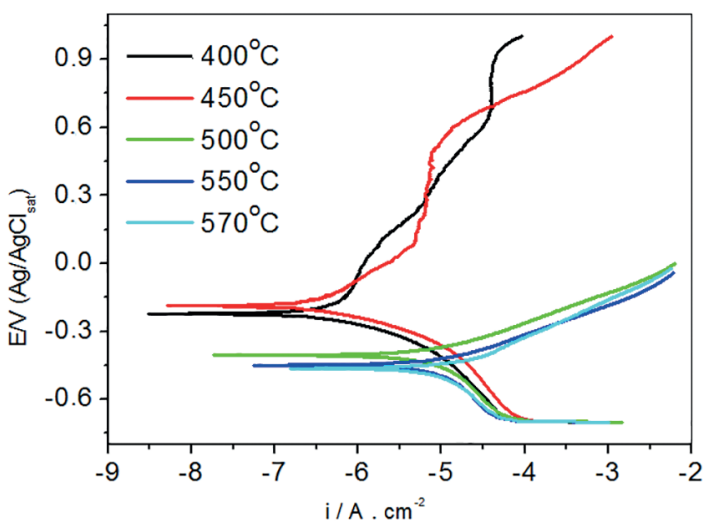

Figure 14: F-53 steel potentiodynamic polarisation curve at different nitriding temperatures for a $0.6 \mathrm{M} \mathrm{NaCl}$ solution and a $0.5 \mathrm{mV} . \mathrm{s}^{-1}$ rate.

Regarding the other temperatures, the corrosion resistance is thought to diminish as the $\mathrm{Cr}_{2} \mathrm{~N}$ content of the material increases. However, we did not verify whether this precipitate actually controlled the $\mathrm{E}_{\text {corr }}$ values that were found in the tests in this study.

$\mathrm{Silva}^{24}$ reported that nitride nucleation occurs in defects, inclusions, grain contours and interfaces. In duplex steels, $\mathrm{Cr}_{2} \mathrm{~N}$ rods or $\mathrm{CrN}$ platelets precipitate from ferrite. Modenesi ${ }^{25}$ reported that under thermal treatment, $\mathrm{Cr}_{2} \mathrm{~N}$ precipitation occurs in the $\delta / \delta$ or $\delta / \gamma$ grain contours. Secondary austenite is one of the products of $\mathrm{Cr}_{2} \mathrm{~N}$ formation, which leads to $\mathrm{Cr}$-impoverishment and deteriorates the corrosion resistance of the alloy.

Weiss et al. ${ }^{26}$, Southwick et al. ${ }^{27}$, Brandi et al..$^{28}$, Hertzman et al. ${ }^{29}$, Ramirez et al. ${ }^{30}$, Brandi et al. ${ }^{31}$ and Lippold et al. ${ }^{32}$ have reported that the most relevant solid state phase transformations in duplex and super duplex stainless steels are as follows: $\mathrm{M}_{23} \mathrm{C}_{6}$ chromium carbides, the sigma phase $(\sigma)$, the $\alpha$ ' phase $\left(475^{\circ} \mathrm{C}\right.$ embrittlement), chromium nitride $(\mathrm{CrN})$ and secondary austenite. All of these phases are embrittled either by an increase in the hardness, the formation of Cr-poor regions in the microstructure, or modifications to the original chemical composition ${ }^{32}$. 


\section{Conclusions}

F-53 steel without surface treatment exhibited a low wear resistance compared to the material with plasma thermochemical treatment.

More material was removed under a $16-\mathrm{N}$ load than under an 8.3-N load because the more severe test resulted in a highly intense interaction between the surfaces in contact.

The test under the 8.3-N load resulted in the formation of a thin oxide film that interfered with the result and drastically reduced the volume of the substrate that was removed at longer sliding distances.

The material that was treated at $350^{\circ} \mathrm{C}$ had a low wear resistance because the nitrogen layer produced in the test was very thin and $S^{\prime}$ and $\alpha$ ' phases and iron nitride formed without the formation of chromium nitrides.

The material that was treated at $400{ }^{\circ} \mathrm{C}$ exhibited the highest wear resistance of the samples investigated, along with the formation of chromium and iron nitrides and S' and $\alpha$ ' phases with a nitrogen layer that was twice as thick as the layer that formed at other treatment temperatures.

The formation of chromium and iron nitrides and S' and $\alpha$ ' phases was observed at $450{ }^{\circ} \mathrm{C}$. However, the layer thickness was similar to that at $400{ }^{\circ} \mathrm{C}$, although the percentage of nitrogen was more uniform throughout the layer.

The layer that was produced at $500{ }^{\circ} \mathrm{C}$ was much harder and thicker than the layers that formed at other treatment temperatures but had a lower wear resistance. This result was obtained because of the formation of different types of nitrides, such as $\mathrm{CrN}, \mathrm{Cr}_{2} \mathrm{~N}, \mathrm{Fe}_{3} \mathrm{~N}$ and $\mathrm{Fe}_{2} \mathrm{~N}$, which provided high hardness and low wear resistance.

There was a reduction in the wear resistance at $550{ }^{\circ} \mathrm{C}$ and $570{ }^{\circ} \mathrm{C}$ because of the formation of different types of $\mathrm{S}$ ' phases that were in equilibrium with the nitride phase.

The alloys that were nitrided at $400{ }^{\circ} \mathrm{C}$ and $450{ }^{\circ} \mathrm{C}$ exhibited the highest corrosion resistance to the solution medium containing chloride ions. The corrosion resistance is thought to diminish as the $\mathrm{Cr}_{2} \mathrm{~N}$ content in the material increases. Thus, other electrochemical techniques, such as electrochemical impedance spectroscopy (EIS), the scanning vibrating electrode technique (SVET) and the scanning Kelvin probe (SKP), could be used to better characterise the corrosion process.

\section{Acknowledgements}

The authors would like to thank the scientists at the Federal University of São Carlos (Universidade Federal de São Carlos - UFSCar) for performing the plasma ion nitriding thermochemical treatment, the scientists at the University of São Paulo/ Lorena (Universidade de São Paulo - USP/Lorena) for collaborating with us in the X-ray diffraction analyses, the National Council for Scientific and Technological.
Development (Conselho Nacional de Desenvolvimento Científico e Tecnológico - CNPq) for providing a scholarship and Federal Institute Goiano (IF Goiano) for financial support.

\section{References}

1. CE Pinedo. Tratamento superficial para aplicações tribológicas. [Surface treatment for tribological applications]. Metalurgia \& Materiais. 2004;60:162-169.

2. Alves Jr CA, Rodrigues JA. Nitretação dos aços assistida por plasma - variabilidade de uso para as indústrias nacional. [Plasma-aided steel nitriding - use variability for the national industry]. Metalurgia - ABM. 1991;47(398):354-355.

3. Manfrinato MD. Influência da nitretação a plasma no comportamento em fadiga dos aços inoxidáveis austeníticos AISI-SAE 304 e 316 [Effect of Plasma Nitriding on the Fatigue Behaviour of Austenitic Stainless Steels AISI-SAE 304 and 316]. [Dissertation]. São Carlos: Universidade de São Paulo; 2006.

4. Liang W, Bin X, Zhiwei Y, Yaqin S. The wear and corrosion properties of stainless steel nitrided by low-pressure plasmaarc source ion nitriding at low temperatures. Surface and Coatings Technology. 2000;130(2-3):304-308. doi: 10.1016/ S0257-8972(00)00713-1.

5. Solomon HD, Devine TM. Duplex stainless steels: a tale of two phases. Metals Park: American Society for Metals; 1982.64 p.

6. O’Brien 1991; Larsson 1993. Apud Baldin GCA. Caracterização frente à corrosão dos aços inoxidáveis super duplex endurecidos superficialmente por nitretação a plasma [Corrosion characterisation of superduplex stainless steels with surface hardening by plasma nitriding]. [Final paper]. Porto Alegre: Universidade Federal do Rio Grande do Sul (UFRGS); 2010.

7. Gee MG, Gant AJ, Hutchings IM, Kusano Y, Schiffman K, van Acker K, et al. Results from an interlaboratory exercise to validate the micro-scale abrasion test. Wear. 2005;259(1-6):2735. doi: 10.1016/j.wear.2005.02.092.

8. Santos WC, Pereira Neto JO, Silva RO, Rodrigues G, Moreto JA, Manfrinato MD, et al. Apparatus development and study of abrasive microwear behaviour of quenched and tempered AISI 420 steel. Matéria (Rio J). 2015;20(2):304-315. doi: 10.1590/ S1517-707620150002.0031.

9. Rutherford KL, Hutchings IM. A micro-abrasive wear test, with particular application to coated systems. Surface and Coatings Technology. 1996;79(1-3):231-239. doi: 10.1016/02578972(95)02461-1.

10. Hutchings IM. Abrasive and erosive wear tests for thin costings: a unified approach. Tribology International. 1998;31(1-3):5-15.

11. Trezona RI, Allsopp DN, Hutchings IM. Transitions between twobody and three-body abrasive wear: influence of test conditions in the microscale abrasive wear test. Wear. 1999;225-229(Part 1):205-214. doi:10.1016/S0043-1648(98)00358-5.

12. Cozza RC. Estudo do comportamento do coeficiente de desgaste e dos modos de desgaste abrasivo em ensaios de desgaste microabrasivo [Wear coefficient and wear mode transition study in micro-abrasive wear testing]. [Dissertation]. São Paulo: Escola Politécnica da Universidade de São Paulo; 2006. 
13. Tedesco NR. Caracterização do comportamento de desgaste de cerâmicas de alumina densa: efeitos de parâmetros do ensaio do tipo pino no disco [Characterisation of the Wear Behaviour of Dense Aluminum Ceramics: Effects of the Pin Type on Disk Test Parameters]. [Masters Thesis]. São Carlos: Universidade Federal de São Carlos (UFSCar); 2010.

14. Moré Farias MC. Influência da velocidade de deslizamento da carga normal e da transformação martensítica induzida por deformação plástica na resistência ao desgaste por deslizamento dos aços inoxidáveis austeniticos [Influence of sliding velocity, applied load and strain-induced martensitic transformation on the sliding wear resistance of the austenitic stainless steels]. [PhD Thesis]. São Paulo: Escola Politécnica da Universidade de São Paulo; 2004.

15. Quinn TFJ. Review of oxidational wear: Part I: the origins of oxidational wear. Tribology International. 1983;16(5):257-271. doi: 10.1016/0301-679X(83)90086-5.

16. Quinn TFJ. Oxidational wear modelling: I. Wear. 1992;153(1):179200. doi: 10.1016/0043-1648(92)90269-E

17. Dalibon EL, Lasorsa C, Cabo A, Cimetta J, Garc'a N, Brühl SP. Tribological properties of SiNx films on PH stainless steel with and without nitriding as a pre-treatment. Procedia Materials Science. 2012;1:313-320.

18. Callister WD Jr., Rethwisch DG. Ciência e Engenharia de Materiais - Uma Introdução [Materials Science and Engineering]. Rio de Janeiro: Livros Técnicos e Científicos Editora; 2008.

19. Reis RF, Schreiner WH, Borges PC. Nitretação do aço inoxidável AISI $316 \mathrm{~L}$ a altas temperaturas: Influência na camada nitretada [High-temperature nitriding of AISI 316L stainless steel: Effect on the nitrided layer]. Revista Brasileira de Aplicações de Vácuo. 2006;25(3):183-187.

20. Oliveira AM. Nitretação e carbonitretação por plasma em aços inoxidáveis e suas influências nas resistências à corrosão e ao desgaste [Plasma nitriding and carbonitriding in stainless steels and their influences in the corrosion and wear resistances]. [PhD Thesis] São Carlos: Universidade de São Paulo; 2005.

21. Christiansen T, Somers MAJ. On the crystallographic structure of S-phase. Scripta Materialia. 2004;50(1):35-37. doi: 10.1016/j. scriptamat.2003.09.042.

22. Nie X, Leyland A, Mattheus A. Low temperature deposition of $\mathrm{Cr}(\mathrm{N}) / \mathrm{TiO}_{2}$ coatings using a duplex process of unbalanced magnetron sputtering and micro-arc oxidation. Surface and Coatings Technology. 2000;133-134:331-337. doi: 10.1016/ S0257-8972(00)00953-1.
23. Tschiptschin AP, Pinedo CE. Structure and properties of an austenitic stainless steel AISI 316L grade ASTM F138 after low temperature plasma nitriding. Rem: Revista Escola de Minas. 2010;63(1):137-141. doi: 10.1590/S037044672010000100023.

24. Silva ILA. Efeito da Temperatura na Microestrutura e Oxidação de Um Aço Inoxidável Superduplex [Effect of Temperature on the Microstructure and Oxidation of a Superduplex Stainless Steel]. [Masters Dissertation]. Campos dos Goytacazes: Universidade Estadual do Norte Fluminense Darcy Ribeiro; 2010.

25. Modenesi PJ. Soldabilidade dos aços inoxidáveis [Weldability of stainless steels]. Coleção Tecnologia da Soldagem 1. São Paulo: SENAI-SP; 2001. 100 p.

26. Weiss B, Stickler R. Phase instabilities during high temperature exposure of 316 austenitic stainless steel. Metallurgical Transactions. 1972;3(4):851-866. doi: 10.1007/BF02647659.

27. Southwick PD, Honeycombe RWK. Decomposition of ferrite to austenite in $26 \% \mathrm{Cr}-5 \% \mathrm{Ni}$ stainless steel. Metal Science. 1980;14(7):253-261. doi: 10.1179/030634580790426418.

28. Brandi SD, Padilha AF. Weldability of duplex stainless steel UNS S31803. In: Proceedings of $73^{\text {rd }}$ American Welding Society Annual Meeting; 1992 Mar 22-27; Miami, FL, USA. p. 22-23.

29. Hertzman S, Roberts W, Lindenmo M. Microstructure and properties of nitrogen alloyed duplex stainless steel after welding treatments. In: Proceedings of Duplex Stainless Steel 86 International Conference; 1986 Oct 26-28; The Hague, Netherlands. p. 257-267.

30. Ramirez AJ, Lippold JC, Brandi SD. The relationship between chromium nitride and secondary austenite precipitation in duplex stainless steels. Metallurgical and Materials Transactions A. 2003;34(8):1575-1597. doi: 10.1007/ s11661-003-0304-9.

31. Brandi SD, Lippold JC, Lin W. Effect of preheat temperature on multipass HAZ performance of duplex stainless steels. In: Proceedings of $76^{\text {th }}$ American Welding Society Annual Meeting; 1995 Apr 2-7; Cleveland, OH, USA. p. 32.

32. Lippold JC, Lin W, Brandi SD, Varol I, Baeslack III WA. Heat affected zone microstructure and properties in commercial duplex stainless steels. In: Proceedings of Fourth International Conference Duplex Stainless Steels (Duplex 94); 1994 Nov 13-16; Glasgow, Scotland. Paper 116. 